\title{
How Singapore's Sovereign Debt Risk Has Changed from 2016 to 2021
}

\author{
Tara Kou $^{1}$ \\ ${ }^{1}$ Dulwich College of Singapore, Singapore \\ Correspondence: Tara Kou, Dulwich College of Singapore, 308144, Singapore.
}

Received: October 25, 2021

Accepted: December 25, $2021 \quad$ Online Published: December 28, 2021

doi:10.5539/ijef.v14n1p91

URL: https://doi.org/10.5539/ijef.v14n1p91

\begin{abstract}
In this paper, I build an economic model and adapt it to fit Singapore's economic and historical background. My empirical analysis is based on data about external debt to GDP, foreign investment, and net export products and partners. But I also address concerns about risk factors coming from covid and the oil crisis. In my analysis, even in the worst case, Singapore is not going to be worse than the Netherlands in the IIR rating, which corresponds to an IIR rating of 90. In contrast to my baseline, risk assessment for Singapore is a rating of 93.
\end{abstract}

Keywords: Singapore, IIR rating 2021, sovereign debt risk

\section{Introduction}

Chari A wrote in "National Bureau of Economic Research", "Default at its simplest is a broken promise, or a breach of contract. For sovereign debt, such a breach could include a missed payment, involuntary subordination, or data misreporting." Sovereign defaults have received considerable attention in the academic literature from leading modern-day economic historians. According to Reinhart and Rogoff, "Sovereign default is defined as the failure of a government to meet a principal or interest payment due date (for within the specified grace period)." In other words, this happens when the government is either unable or unwilling to make good on its fiscal promises to repay its bondholders. Of course, not all defaults are the same. In some cases, the government misses an interest or principal payment. Other times, it merely delays a disbursement. The government can also exchange the original notes for new ones with less favorable terms.

When a country does default, it can take years to recover. Sovereign default may result in a government facing higher interest rates and a lower credit rating among lenders, making it more difficult to borrow. Perhaps the biggest concern about a default, however, is the impact on the broader economy. In the United States, for instance, many mortgages and student loans are pegged to Treasury rates. If borrowers were to experience dramatically higher payments as the result of a debt default, the result would be substantially less disposable income to spend on goods and services.

In the paper, I interpret the IIR rating for 2021, which is unknown. Investors who are interested in Singapore treasury bonds and care about default risk need a measure of Singapore's future sovereign debt risk. One measure is the IIR rating, which is the measure Rinehart and Rogoff mentioned in their book. However, the latest IIR rating for Singapore is for 2016. In other words, the IIR rating of 2021 is unknown. It has been discontinued, since there is no corresponding measure for 2021.

I fill this gap by investigating Singapore's historical background, building economic models, and analyzing data. Data analysis is informed by solid economic theory and by details about the historical economic background drawn from Singapore's history. What I do to create new knowledge. I also provide an assessment of the risk by analyzing Singapore's external debt to GDP, bond yield, investment and export. This paper could be a suggestion or evidence for investors looking to buy treasury bonds and investors speculating about Singapore's sovereign debt.

Based on analyses of Singapore, the IIR rating for 2021 will remain in a relatively same position (6th) and will be no lower than Netherland (9th). Singapore will be in a strong position in 2021 due to its increasing foreign investments and stable export. Potential risk factors including covid and the oil price crisis should not be of concern. 


\section{Historical Background}

Singapore has had no defaults in its economic history but its birth pangs were traumatic. Separation from Malaysia in 1965 meant the loss of its economic hinterland. With the announcement of Britain's departure in 1968, Singapore faced the loss of 20 percent of its jobs, causing a consequent reduction in the GDP. The government decided to shift away from import-substitution in favor of export-led industrialization and to attract global multinational corporations as vehicles to achieve industrial growth. "The explosion of trade experienced by all led to rapid city growth." The government policies increased industrial growth and solved the domestic problems of unemployment, population growth, and housing. Inflation was kept low by the government's conservative fiscal policies, which included the maintenance of strict control over the money supply.

The government aggressively promoted export-oriented, labor-intensive industrialization through a program of incentives designed to attract foreign investment. The 1973 oil shock caused Singapore's growth rate to average 8.7 percent between 1973 to 1979, which was high compared with other countries. One of the fastest growing sectors of the economy was Singapore's international banking and financial services sector, which accounted for nearly 25 percent of the country's GDP in the late 1980s. Historically, Singapore served as the financial services center for Southeast Asia, and in the late 1980s it ranked with Hong Kong as the two most important Asian financial centers after Tokyo. According to Bryant in his paper "A brief financial history "the Singapore government vigorously encourages the location of financial-intermediary activities in Singapore, thereby promoting Singapore as a 'financial center."' Given Singapore's dependence on the world economy, the 1985 recession was the worst in the nation's history due to the decline of foreign demands. The government responded by freezing overall wage levels, reducing corporate income taxes, reducing personal income taxes, and introducing an across-the-board investment allowance to encourage greater investment in equipment and machinery. By 1988 Singapore's economy had rebounded. Between 1970-1990, The PAP developed a stable and corruption-free government, marked by strong central development planning and social policies. GDP growth in the 1990s was linked closely with export growth and expansion of the electronics industry. "From 1980 to the 1990s the country was particularly focused on information technology; by the end of the 1980s, 30 percent of its GDP was due to revenues from manufacturing, followed by its service and financial industry with 27 percent. The financial sector has been one of the fastest growing industries in the country's economy, with several thousand financial and trading firms catering to 650 multinational companies" (Aleles, n.d.). Singapore was hit hard by the 1997-1998 Asian financial crisis but not as hard as some of its Asian neighbors since it had a budget surplus, a strong currency, lots of hard currency reserves, and low inflation. In 1998, the government announced $\$ 6.5$ billion in budget cuts and improved corporate transparency, allowing more foreign control of its companies and banks. Nowadays, Singapore's economy is mainly driven by exports in electronics manufacturing and machinery, financial services, tourism, and the world's busiest cargo seaport.

\section{Method}

This section describes my economic framework. I begin with a textbook macroeconomic model, where the fundamental equation for GDP is $\mathbf{Y}=\mathbf{C}+\mathbf{I}+\mathbf{G}+\mathbf{E X}-\mathbf{I M}$, where $\mathbf{C}$ is consumption level, $\mathbf{I}$ is investment, $\mathbf{G}$ is government spending, $\mathbf{E X}$ is export, and IM is import.

I will now adapt the model to fit the case of Singapore. My first assumption is that $\mathbf{C , ~} \mathbf{G}$ and $\mathbf{I M}$ are constant. This assumption is reasonable because the consumption level, government spending, and import have not changed a lot since 2016.

This puts the focus on investment and exports. Recall from the historical background section the importance of export and investment in Singapore's economy.

In principle, all these variables interact in potentially complex ways, but under my assumption, if Singapore has an increase in foreign investment and exports, then I and EX will go up, leading to an increase in GDP.

Default probability goes down when Singapore's government revenue rises relative to expenditure. Singapore's expenditure includes debt-service cost and government payments.

As for debt-service cost, it is equal to $\frac{\text { Debt }}{\mathbf{P} \times \mathbf{Y}}$, where $\mathbf{P}$ is price level and $\mathbf{Y}$ is GDP. I assume that debt is constant, because debt determined in the past ten years is fixed. Price level is also constant in my assumption. Singapore's low and stable inflation roughly corresponds to the assumption of constant prices. Since debt and price are both constant, the increase in $\mathbf{Y}$ due to the increase in investment and export will lower the debt service cost. 
Government payment is the payment from the government to stimulate the economy during a recession. If GDP goes up due to a rise in I and EX, the government could spend less in stimulating the economy, and thus government payments will reduce. As a result, with a decrease in both debt service cost and government payments, expenditure will fall.

Government revenue is tax revenue, which is $\mathbf{t} \times \mathbf{P} \times \mathbf{Y}$. I assume the tax rate $\mathrm{t}$ is constant since the tax rate to GDP in the past ten years is roughly constant. As we have mentioned before, price level $\mathrm{P}$ is also constant. Therefore, with an increase in $\mathrm{Y}$, tax revenue increases. In this circumstance, government revenue will increase.

Since government revenue increases while expenditure decreases, default probability goes down.

\section{Data}

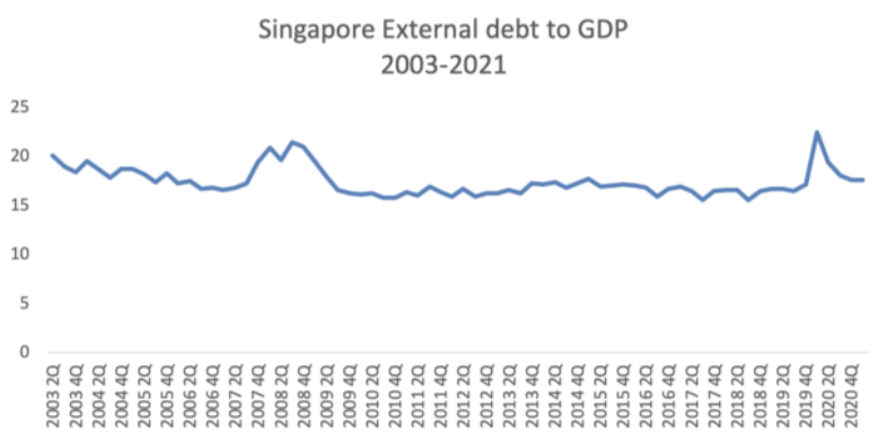

Figure 1. Singapore external debt to GDP from 2003-2001

Source: CEIC.

External debt is the total liabilities of a country with foreign creditors, both official and private. External debt to GDP illustrates the amount of money the Singapore government has borrowed, which allows us to infer the possibility of default of sovereign debt. The data range from 2003-2020. Singapore external debt to GDP is relatively unchanged, and flat. There are some spikes in between, one between 2007-2008 due to the global financial crisis and the other one between 2019-2020 due to covid-19, which are understandable and reasonable. Besides, Singapore has a low external debt to GDP, normally we say that it is safe below 120, but we could see from Figure 1 that Singapore's external debt to GDP is below 25, indicating that Singapore has low borrowings. Therefore, it is nearly impossible for this country to default.

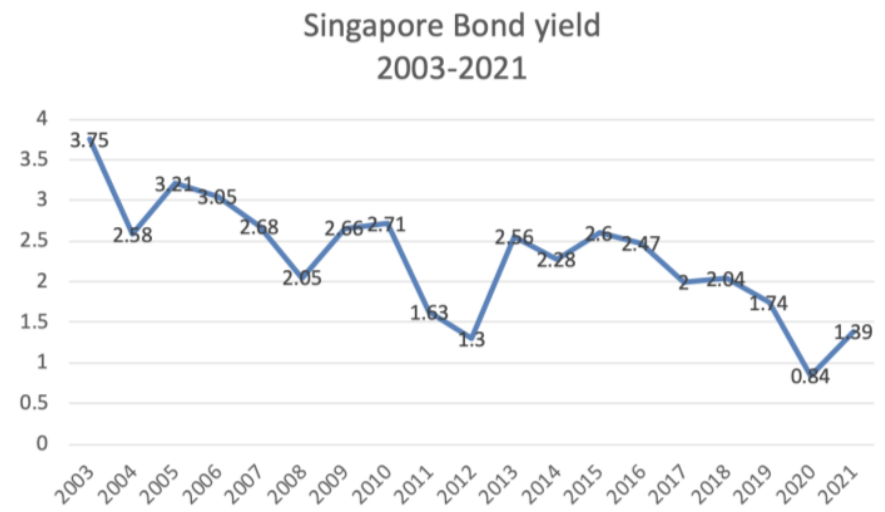

Figure 2. Singapore bond yield rate from 2003-2021

Source: FRED.

Bond yield is the return an investor realizes on a bond, which is expressed as interest rate. It represents the market beliefs of the risk of the Singapore sovereign debt, so the lower the number, the lower the risk. The data range from 2003 to 2021. The overall trend has decreased since 2003, and reached its minimum point in 2020. As for the bond rate minus inflation rate, the graph decreases in a steeper way. There are two spikes between 2007 to 2008 and between 2011 and 2012. The former is due to the global financial crisis and the latter is due to the great recession. 
Table 1. Comparison of rating between 2016 and 2021

\begin{tabular}{ccc}
\hline IIR rating & 93.2 & same position \\
Bond rate & 2.47 & 1.39 \\
Inflation rate & -0.53227 & $-0.18192(2020)$ \\
External debt to GDP & 16.687908 & 17.605788 \\
\hline
\end{tabular}

Sources: FRED, Institutional Investor.

IIR rating is used to measure a country's fragility as a foreign borrower. According to its definition, it is "based on survey information provided by economists and sovereign risk analysts at leading global banks and securities firms." The higher the rating of the countries, the lower the likelihood of defaulting on their government debt obligations. This acts as evidence to show that markets speculate lower risk of Singapore sovereign debt. In Table 1, the bond rate decreases, indicating that the market believes Singapore debt is less risky than other investments people could be making.

Table 2. Singapore five major export partners

\begin{tabular}{lcc}
\hline Market & Trade $(\$$ US million) & Partner share $(\%)$ \\
\hline China & 51,619 & 13.22 \\
Hong Kong, China & 44,377 & 11.37 \\
Malaysia & 41,152 & 10.54 \\
United States & 34,401 & 8.81 \\
Indonesia & 27,359 & 7.01 \\
\hline
\end{tabular}

Source: World Integrated Trade Solution.

Table 3. Singapore export products categories

\begin{tabular}{lcc}
\hline Product Categories & \multicolumn{2}{c}{ Exports } \\
\cline { 2 - 3 } & Export (\$US million) & Product share $(\%)$ \\
\hline Raw material & 3,675 & 0.94 \\
Intermediate goods & 70,780 & 18.13 \\
Consumer goods & 99,420 & 25.47 \\
Capital goods & 194,886 & 49.93 \\
\hline
\end{tabular}

Source: World Integrated Trade Solution.

Table 4. Singapore top five export products and quantity

\begin{tabular}{lc}
\hline & Exports \\
\hline Monolithic integrated circuits, digital & $75,952,597.66$ \\
Petroleum oils & $45,882,931.23$ \\
Gold in semi-manufactured forms & $11,452,170.91$ \\
Transmission apparatus & $8,642,881.42$ \\
Parts and accessories of automatic data process & $7,436,910.50$ \\
\hline
\end{tabular}

Source: World Integrated Trade Solution.

Table 2 shows five major trading partners of Singapore: China, United States, Malaysia and Indonesia. Looking at trading partners helps to illustrate the stability of Singapore exports. If Singapore's trading partners do not stable economy, then their demand for products is not stable, and, therefore, Singapore's exports would not be stable. Conversely, if Singapore's partners have a strong economy, then Singapore has a safe export. In Table 2, we know that most countries like China, USA and Malaysia are still growing rapidly, meaning that they will continually have a high demand towards the products, especially high-tech products, leading to a stable export. China is the biggest export partner of Singapore. There are three developing countries and one developed country, but all of them are still expanding rapidly. Table 3 shows the product share of different categories of products. Capital goods occupy the largest share. Table 4 shows the Top .5 export products of Singapore, which include technological products, oil and gold. Technological products occupy the largest share. 


\section{Analysis}

\subsection{Investment}

Despite a global pandemic, Singapore is still drawing investments from global tech firms. As the US-China tech race heats up, more firms are flocking to Singapore in a bid to escape the fallout. Many of them have been here for some time, including Google, IBM and Microsoft. Those which have arrived or expanded their investments in recent months are among the fastest-growing firms from their respective tech hubs in the US and China namely Zoom, Twitter, PayPal, Tencent, Alibaba, and Byte Dance.

In the first half of 2020, Singapore has already drawn $\mathbf{S \$ 1 4 . 3}$ billion in fixed-asset investments - this is 95 per cent of the total investment commitments for 2019. Around 80 of the world's top 100 technology firms have a sizable presence in the tiny island of Singapore.

There are four reasons why companies move to Singapore:

\section{1) Ease of starting a business}

It is easier and quicker to register a company in Singapore as the process takes only one day to complete given all the proper requirements are completed and the application is duly submitted. Owning a company in Singapore can be set up by anyone including foreigners. An easy and fast procedure availability of an online system has been made by the incorporation where you can submit your application forms via the internet on-line. According to the World Bank business indicator, Singapore ranks 4th in the world for starting a business.

\section{2) high personal safety}

Singapore has one of the most stable political environments in Asia, offering entrepreneurs and investors a strong sense of security and comfort. Its judicial system has been recognized as one of the most efficient in Asia, enforcing anti-corruption laws so that investors can conduct business without fear of bureaucratic malaise.

Moreover, through strict law enforcement, Singapore has a persistently low crime rate and offers residents a high degree of personal safety. In the event of cross-border disputes, businesses can rely on Singapore's reputation as a world-class arbitration facility.

3) Comprehensive intellectual property protection

According to the World Economic Forum's Global Competitiveness Report 2015 - 2016, Singapore offers the best IP protection, infrastructure and incentives in Asia. It also is a close second in that ranking globally, next to Finland and Luxembourg, which tied in first place.

\section{4) Attractive corporate law rate}

Singapore also offers one of the most attractive corporate tax structures in the world. Although its marginal rate is the third lowest in the world, its effective tax rate is even lower, compared to other more developed countries. The first three years the taxable income of non-resident corporations is exempted from taxes where it is considered a "zero tax" jurisdiction. Avoidance of Double Tax Agreements (DTAs) is also entered into by the Singapore government with other international jurisdictions in order to ensure the country' financial success and prosperity.

\section{5) Singapore strong common law legal system}

According to the World Bank, Singapore ranks 1st in enforcing contracts. Singapore's legal system has been described in this way "Characterized by universal applicability and conformity to international norms, 'universalism' distinguishes the legal regime governing economic activity in Singapore" in the paper"Law and values in governance: The Singapore way".

a) It is flexible and open to innovation.

This is particularly important for businesses operating in innovative sectors such as technology and financial services. Courts try to find logical solutions to novel issues by building upon existing case law precedent without having to wait for new legislation. The law can adapt quickly to commercial innovation unforeseen by legislators in a way that the more prescriptive and controlling civil law systems cannot.

b) Certainty

The highly "purposive" method of legislative interpretation in civil law systems (such as that of the EU) can lead to unpredictability and inconsistency between different judges. In contrast, the emphasis on judicial precedent in common law systems enables businesses to predict legal outcomes with a much higher degree of certainty.

c) Singapore judges are known and respected for understanding of complex business issues 


\subsection{Export}

According to its historical background, Singapore has always been an export-orientated country. Therefore, Singapore's export performance will definitely influence its GDP. According to the aforementioned data, Singapore's major export partners are mostly developing countries like China, Malaysia and Indonesia. These countries are rapidly developing, and thus their demand is not likely to fall. Additionally, Singapore's top export products include oil and technological products. Technological products are safe in my opinion, since the demand for electronics likely won't reduce, especially within the rapid technological developing era. Countries will always need these products. Therefore, there's no expectation that these major countries would shift away their demand for technology. As for oil, it has certain potential risks and thus is not as safe as technology. People may pay less for oil if there are more electric cars or people are more concerned about environmental problems. This will lead to a collapse in world oil prices, which will hurt Singapore oil exports. World price is vulnerable and uncontrollable, so Singapore may be affected by the change in the world price, leading to a decrease in exports and thus lower its GDP. However, I still remain positive about oil exports because countries need oil as fossil fuel to produce all products, so if the global economy is strong, there will be a large demand for oil. Also, the major trading partners like China, the US and Hong Kong all have a strong economy and are also buying other products from Singapore, therefore their demand is considered relatively stable. And thus, there's less worry of a decline in net export.

\section{Conclusion}

Based on my analysis of Singapore's increase in export and investment due to stable demand for technological products (Table 3) and migration of foreign companies, it leads me to think that Singapore's 2021 IIR rate will remain in relatively the same position. As same with the US, Singapore debt didn't change for the last several years and is even lower and more stable than the US. Therefore, Singapore IIR rating will remain above 90.

There are several reasons that lead me to this conclusion. Firstly, recall from my analysis section that we saw that numerous companies migrate to Singapore in the past two years, which increase foreign investment, and thus stimulate Singapore's GDP. Secondly, Singapore has a stable export, since most of its exports are technological products (Table 3), so the demand is relatively stable. Its trading partners are mostly developing countries with strong economies, which will have a large demand due to rapid development.

The only factor that may cause a decrease in Singapore IIR rating is covid and world oil price decrease. However, since covid-19 impacts the whole world, all countries have some degree of decrease in their GDP. However, investors may choose a country that encountered less of an impact from covid. In this way, Singapore definitely stands out. Singapore has fewer covid cases than most of the country, and its shut down period is relatively short. Singapore's GDP is still positively growing during the covid period and it is recovering quickly. Therefore, even though Singapore is affected by covid, it is still a better option for investors than other countries. As for oil exports, a fall in world oil prices may cause a decrease in Singapore's exports, but I am personally not worried about this. Recall Singapore's five major partners, they are all developing countries, so they have a large demand in oil as fuel to develop their country. Therefore, their demand for oil is relatively stable.

As I have mentioned, Singapore's IRR lower bond is 90, which corresponds to the rating for the Netherlands. According to the World Bank, the Netherlands ranks $42^{\text {nd }}$ in the ease of doing business, ranking while Singapore ranks $2^{\text {nd }}$. Singapore ranks far better than the Netherlands for almost all of the sections except for trading across borders, where the Netherlands is the $1^{\text {st }}$. Since the Netherlands is in the European Union, it has beneficial trading policies. However, Singapore has a strong relationship with its five trading partners, as mentioned in Table 1 in the data section. Therefore, Singapore will definitely stay higher than the Netherlands. Besides, according to my previous analysis, oil risk is a concern for Singapore. However, oil is the top export product for the Netherlands, and thus if the oil market collapses, the Netherlands will collapse too, and even more seriously than Singapore. So, Singapore is not inferior to the Netherlands.

As a result, I conclude that Singapore's sovereign will continue to be low risk, so investors can buy the bonds. Based on the historical trend that Singapore has no default history, I expect the same trend to continue in the future. Therefore, buying Singapore treasury bonds will be a safe investment.

\section{References}

Bryant, R. C. (2019). A Brief Financial History. The Management of Success: The Moulding of Modern Singapore.

Chari, A., Leary, R., \& Phan, T. (2017). The costs of (sub) sovereign default risk: Evidence from puerto rico (No. 
w24108). National Bureau of Economic Research. https://doi.org/10.3386/w24108

Giron, D. (2019). Singapore; brief insight into its history and urban development. Unpublished manuscript.

Huff, W. G. (1997). The economic growth of Singapore: Trade and development in the twentieth century. Cambridge University Press.

Reinhart, C. M., \& Rogoff, K. S. (2009). This time is different. Princeton university press. https://doi.org/10.1515/9781400831722

Tan, E. K. B. (2000). Law and values in governance: The Singapore way. Hong Kong LJ, 30, 91.

\section{Copyrights}

Copyright for this article is retained by the author(s), with first publication rights granted to the journal.

This is an open-access article distributed under the terms and conditions of the Creative Commons Attribution license (http://creativecommons.org/licenses/by/4.0/). 